\title{
A spatial approach to rainfall in Sertão do Pajeú - Pernambuco
}

\author{
Uma abordagem espacial da precipitação pluviométrica no Sertão do Pajeú - Pernambuco \\ Un enfoque espacial de la lluvia en Sertão do Pajeú - Pernambuco
}

Received: 08/19/2021 | Reviewed: 08/25/2021 | Accept: 08/27/2021 | Published: 08/30/2021

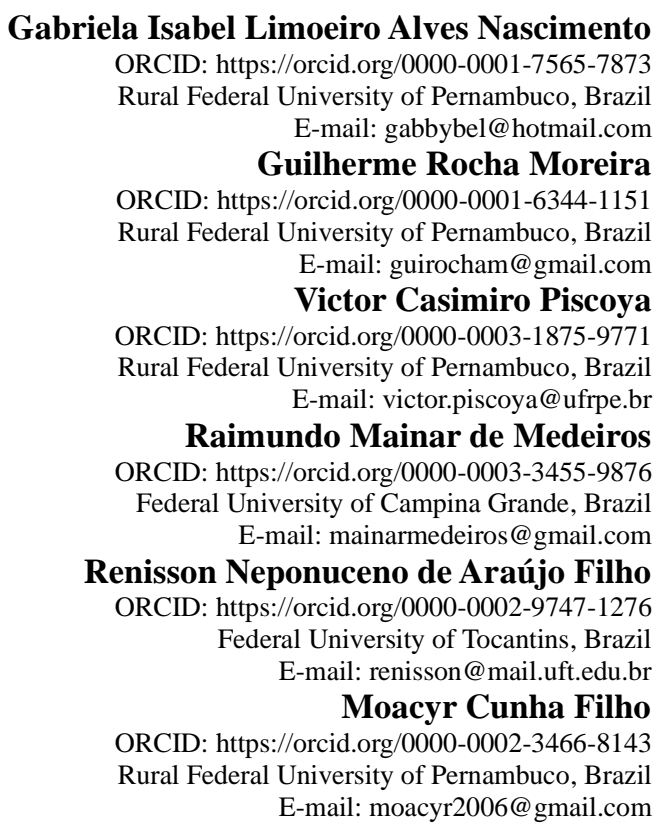

\begin{abstract}
Changes in precipitation have implications for the hydrological cycle and water resources. Climate change is expected to alter average temperature and precipitation values, increasing the variability of these events, which could cause more intense and frequent floods and droughts. The objective of this study was to characterize the rainfall in the microregion of Pajeú, in Pernambuco, as well as to provide subsidies for public policies aimed at water scarcity. For this, rainfall data were used at stations belonging to the micro-region and its surroundings, for the period from January 1980 to December 2019. In addition, to mitigate the influences caused by temporal heterogeneity, stations with large discontinuity of information. The Inverse Weighted Distance was used to perform the interpolation of data and preparation of maps with isolines of rainfall. The results show the places with the highest annual rainfall during the study period were Serra Talhada and Triunfo, and the lowest rainfall occurred in the vicinity of Ingazeira and Tabira.
\end{abstract}

Keywords: Rainfall; Interpolation; Pajeú; Pernambuco; Brazil.

\section{Resumo}

Mudanças na precipitação têm implicações no ciclo hidrológico e nos recursos hídricos. Espera-se que as mudanças climáticas alterem temperatura média e os valores da precipitação, aumentando a variabilidade desses eventos, que poderão causar inundações e secas mais intensas e frequentes. O objetivo deste estudo foi caracterizar a precipitação pluviométrica na microrregião do Pajeú, em Pernambuco, bem como fornecer subsídios para as políticas públicas voltadas à escassez hídrica. Para isso, foram utilizados dados da precipitação pluviométrica nos postos pertencentes à microrregião e ao seu entorno, relativos ao período de janeiro de 1980 a dezembro de 2019. Ademais, para mitigar as influências ocasionadas pela com a heterogeneidade temporal, foram removidas as estações com grande descontinuidade de informações. Utilizou-se o Inverso da Distância Ponderada para irrealização da interpolação dos dados e elaboração dos mapas com as isolinhas da precipitação pluviométrica. Os resultados apresentam os locais com maior precipitação anual durante o período de estudo foram Serra Talhada e Triunfo, e, as menores precipitações ocorreram nas proximidades de Ingazeira e Tabira.

Palavras-chave: Precipitação Pluviométrica; Interpolação; Pajeú; Pernambuco; Brasil.

\section{Resumen}

Los cambios en las precipitaciones tienen implicaciones para el ciclo hidrológico y los recursos hídricos. Se espera que el cambio climático altere los valores promedio de temperatura y precipitación, aumentando la variabilidad de 
estos eventos, lo que podría provocar inundaciones y sequías más intensas y frecuentes. El objetivo de este estudio fue caracterizar las precipitaciones en la microrregión de Pajeú, en Pernambuco, así como otorgar subsidios para políticas públicas orientadas a la escasez de agua. Para ello, se utilizaron datos de precipitación en estaciones pertenecientes a la microrregión y sus alrededores, para el período de enero de 1980 a diciembre de 2019. Además, para mitigar las influencias provocadas por la heterogeneidad temporal, estaciones con gran discontinuidad de información. La Distancia Ponderada Inversa se utilizó para realizar la interpolación de datos y preparación de mapas con isolíneas de lluvia. Los resultados muestran que los lugares con mayor precipitación anual durante el período de estudio fueron Serra Talhada y Triunfo, y la menor precipitación ocurrió en las cercanías de Ingazeira y Tabira.

Palabras clave: Lluvia; Interpolación; Pajeú; Pernambuco; Brasil.

\section{Introduction}

Changes in rainfall behavior affect the hydrological cycle and conse-quently water resources. In cases of extreme climate change, the impactis related to changes in water resources, the occurrence of more severeand frequent floods and droughts (Silva et al, 2017). Therefore, it is relevant to carry out research studies on rainfall, they are important to support actions aimed at water resources, in particular the study region, which belongs to the semiarid region.

In the literature there are several data interpolation techniques. In Inverse Weighted Distance (IDW), the area of influence of each sample decreases as the distance increases in relation to another sample (Mazzini \& Schettini, 2009). In this case, the sample weights during the interpolation technique are inversely proportional to the distance from the mesh node. (Santos et al., 2014).

In this context, Soares et al., (2014) were successful in applying the interpolation by IDW in his studies on the spatial and temporal distribution of precipitation in the hydrographic region of Ilha Grande Bay in the state of Rio de Janeiro. In turn, Santos et al., (2014) used the IDW to study the spatial and temporal variability of rainfall for the microregion of Pau dos Ferros, Rio Grande do Norte. Thus, the Inverse of Distance represents a commonly used interpolation technique.

Furthermore, the application of geostatistics is also applied to the data with interpolation techniques for construction of the estimated surface, in order to identify the best fit, as in the works of Carvalho and Assad (2005), Júnior et. al. (2012) and Franco and Uda (2015). In addition, studies on rainfall in municipalities and states in Brazil are carried out, Cunha et. al. (2013), Pires et. al (2016), Mello and Oliveira (2016) e Medeiros et. al (2021) contributing to a greater depth in the analyses.

In this sense, the research aims to characterize the rainfall in the microregion of Pajeú, in Pernambuco, as well as to provide subsidies for public policies aimed at water scarcity. In the next section, the method used for interpolation of rainfall is presented, considering data from the last 40 years.

\section{Methodology}

This is a quantitative, descriptive study, whose main purpose is to describe the characteristics of a given population or phenomenon (Sampieri et. al., 2013).

\subsection{Study Area}

The state of Pernambuco is subdivided into five mesoregions and nineteen microregions (IBGE, 2017). The study area is part of the Sertão mesoregion and corresponds to the group of municipalities in the Pajeú Pernambucano microregion with an approximate area of $8,770 \mathrm{~km}^{2}$ and corresponds to $8.95 \%$ of the Pernambucano territory (IBGE, 2020).

The microregion of Pajeú borders the microregions of Sertão do Moxotó, Itaparica and Salgueiro, in Pernambuco and the state of Paraíba (Figure 1). According to the IBGE (2021), the population corresponds to 333,724 inhabitants and represents $3.47 \%$ of the state's population. 
Figure 1. Geographical location of the study area and the municipalities belonging to the microregion of Pajeú - Pernambuco.

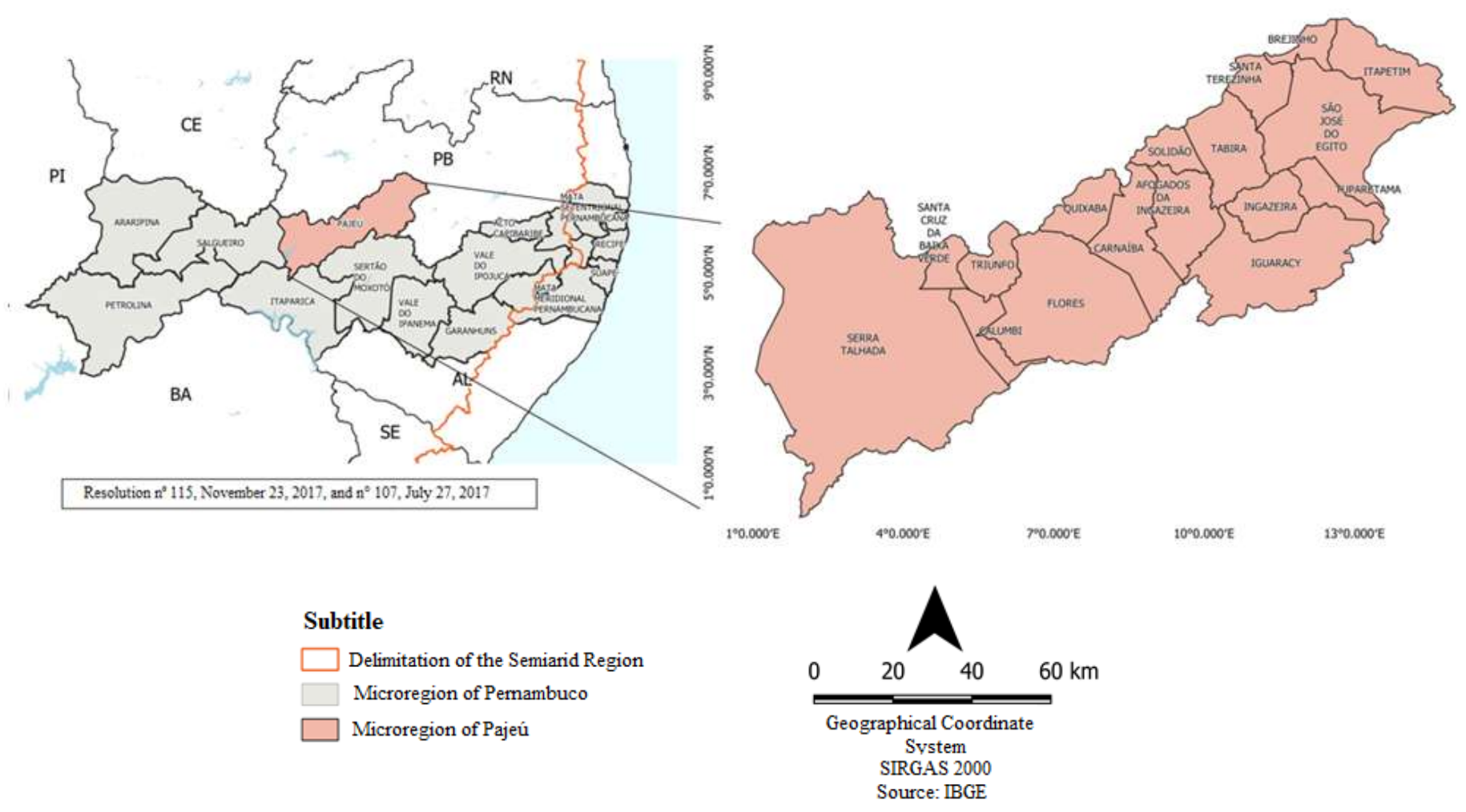

Source: Prepared by the Authors (2020)

\subsection{Data}

The data come from the National Agency for Water and Basic Sanitation (ANA), using information from rainfall stations, including stations belonging to the municipalities of the microregion of Pajeú and stations hosted in surrounding municipalities. Stations with great discontinuity of information were removed to mitigate the influences caused by temporal heterogeneity.

According to the World Meteorological Organization (WMO), for climatological studies, it is recommended that the historical series consider at least thirty years, in this way, average precipitation data from January 1980 to December 2019 were used. Finally, the treatment and data analysis using R and QGIS software.

\subsection{Interpolation Technique}

According to Yamamoto and Landim(2013), the process of reproduction of the characteristics of the spatial phenomenon based on sampling points is called interpolation or estimation. The interpolation of an unsampled point is performed by fitting local (points closest to the unsampled point) or global (all sampling points) mathematical functions.

For data interpolation, Inverse Distance Weighting - IDW was used, method proposed by Shepard (1968) as global interpolation method. This technique is frequently used and consists of assigning the greatest weight to the nearest point, decreasing the weight as the distance increases as a function of a power coefficient $(\alpha)$. Its mathematical formulation can be described as follows:

$$
\hat{Z}(x)=\frac{\sum_{i=1}^{n} Z\left(x_{i}\right) \frac{1}{d_{i j}^{\alpha}}}{\sum_{i=1}^{n} \frac{1}{d_{i j}^{\alpha}}}
$$


where $\hat{Z}$ corresponds to estimated values, $x$ represents the number of samples, $x_{i}$ the known values, $d_{i j}$ the distance between the points $i$ and $j$, (Camargo, 1998).

\section{Results and Discussion}

Initially, the collection and processing of data was carried out, identifying the stations with information with greater constancy of information. Thus, for the analysis, data from twenty pluviometric stations were used, among which thirteen belonging to the microregion of Pajeú and seven were located in surrounding municipalities, including the municipality of the State of Paraíba, Tables 1 and 2, respectively.

Table 1. List of selected locations and their geographic coordinates of municipalities belonging to the microregion of Pajeú ${ }^{1}$, for the historical series from January 1980 to December 2019.

\begin{tabular}{lll}
\hline Municipalities & Latitude & Longitude \\
\hline Afogados da Ingazeira & -7.74295 & -37.6252 \\
Brejinho & -7.34566 & -37.2897 \\
Carnaíba & -7.79430 & -37.7913 \\
Flores & -8.04636 & -37.8329 \\
Iguaracy & -7.84256 & -37.5415 \\
Ingazeira & -7.69161 & -37.4894 \\
Itapetim & -7.37536 & -37.1902 \\
Quixaba & -7.71775 & -37.8494 \\
Santa Cruz da Baixa Verde & -7.88839 & -38.197 \\
São José do Egito & -7.50761 & -37.2749 \\
Serra Talhada & -7.99341 & -38.2938 \\
Triunfo & -7.83051 & -38.1056 \\
Tuparetama & -7.63308 & -37.3279 \\
\hline
\end{tabular}

${ }^{1}$ No collection points were found for the municipalities of Calumbi, Santa Terezinha, Solidão e Tabira. Source: Authors (2020).

Table 2. List of selected locations and their geographic coordinates of the municipalities surrounding the microregion of Pajeú, for the historical series from January 1980 to December.

\begin{tabular}{lll}
\hline Municipalities & Latitude & Longitude \\
\hline Betânia & -8.18227 & -37.9812 \\
Custódia & -8.07769 & -37.6526 \\
Floresta & -8.59800 & -38.5810 \\
Mirandiba & -8.09200 & -38.7060 \\
Monteiro & -7.88538 & -37.1267 \\
São José do Belmonte & -7.83268 & -38.7642 \\
Sertânia & -8.42957 & -37.4096 \\
\hline
\end{tabular}

Source: Authors (2020).

The analysis of the behavior of the series over the studied period identified that the year 2004 had the highest average annual precipitation, with $683.98 \mathrm{~mm}$, while the year with the lowest annual average was 2012, with $155.75 \mathrm{~mm}$. In Andrade et. al. (2018), it was possible to identify decreasing trends in the average annual precipitation values in the six microregions of the Agreste region of Pernambuco in the Northeast region of Brazil, with average values around $436.76 \mathrm{~mm}$.

With the interpolated map, it is possible to identify the spatial distribution of rainfall in the Pajeú microregion, as well as to identify the territories with the highest average rainfall, such as the Serra Talhada and Triunfo municipalities, and the places with lower annual rainfall such as in the boundaries between the municipalities of Tabira and Ingazeira (Figure 2). 
Figure 2. Annual averages of precipitation in the microregion of Pajeú in Pernambuco - Brazil for the series from 1980 to 2019.

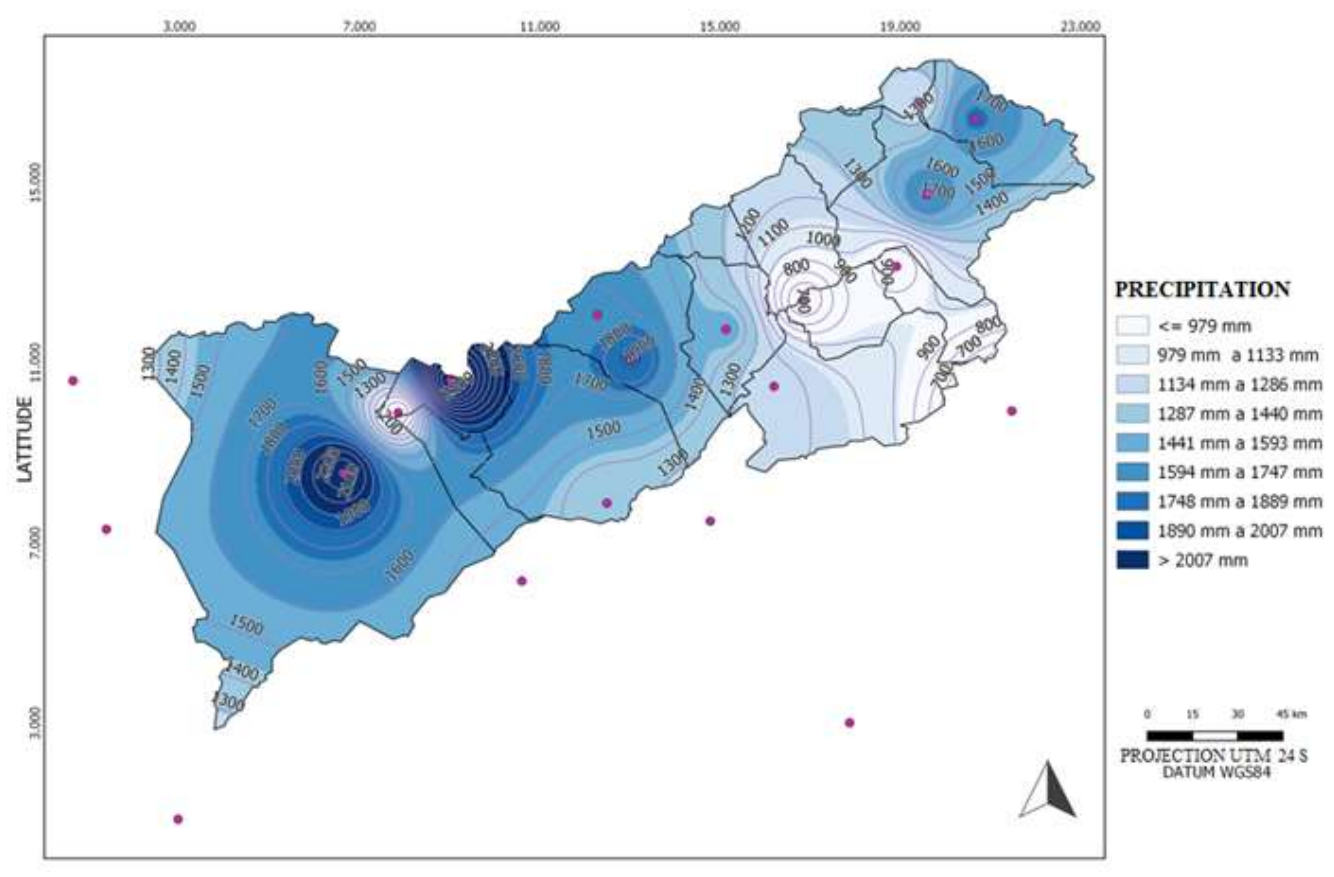

Source: Authors (2020).

\section{Final Considerations}

The interpolation of pluviometric precipitation projects a possibility of using this technique as a tool for the management of water resources in the territory. Based on the use of spatial geotechnology tools with IDW interpolation, the technique proved to be adequate to extract relevant information regarding studies related to the characterization of rainfall in the microregion of Pajeú, in Pernambuco.

Finally, the pluviometric spatial description of the territory provides subsidies for public policies aimed at water scarcity. Thus, in addition to the methodology used in this study, for future work, Geostatistics, as well as other interpolation methods, can also be considered to assist in planning and monitoring the operational development of rainfall networks.

\section{Acknowledgments}

The authors acknowledge the CNPq (National Council for Scientific and Technological Development), CAPES (Coordination for the Improvement of Higher Education Personnel) and FACEPE (Foundation for the Support of Science and Technology of the State of Pernambuco) for support the development of this research.

\section{References}

Agência Nacional de Águas e Saneamento Básico - ANA. https://dadosabertos.ana.gov.br/datasets/8014bf6e92144a9b871bb4136390f732_0.

Andrade, A. R S., Godoy Neto, A. H., Cruz, A. F.da S., Andrade, E. K.P, Santos, V. F. dos, \& Silva, T. N. P. (2018). Geoestatística aplicada à variabilidade espacial e padrões nas séries temporais da precipitação no agreste pernambucano. Journal of Environmental Analysis and Progress. 3(1), 126. https://doi.org/10.24221/jeap.3.1.2018.1668.126-145.

Camargo, E. C. G. (1998). Geoestatística: fundamentos e aplicações. Geoprocessamento para projetos ambientais. INPE, 1-36.

Carvalho, J. R. \& Assad, E. D. (2005). Análise espacial da precipitação pluviométrica no estado de são paulo: comparação de métodos de interpolação. Embrapa Informática Agropecuária - Artigo em periódico indexado (ALICE), SciELO Brasil. 
Cunha, A. de M., Lani, J. L., Santos, G. R. dos, Filho, E. I. F., Trindade, F. S. \& Souza, E. de. (2013). Espacialização da precipitação pluvial por meio de krigagem e cokrigagem. Pesquisa Agropecuária Brasileira, 48(9), 1179-1191.

Franco, A. C. L.\& Uda, P. K. (2015). Comparação de métodos de espacialização da precipitação na bacia do alto rio negro, santa catarina. Anais: XVII Simpósio Brasileiro de Sensoriamento Remoto-SBSR, João Pessoa-PB, Brasil, 25.

IBGE, 2017. Divisão Regional do Brasil. https://www.ibge.gov.br/geociencias/cartas-e-mapas/redes-geograficas/15778-divisoes-regionais-dobrasil.html?=\&t=o-que-e.

IBGE, 2020. Geociências - Organização do Território - Estruturas territorial. https://www.ibge.gov.br/geociencias/organizacao-do-territorio/estruturaterritorial/15761-areas-dos-municipios.html?=\&t=o-que-e.

IBGE, 2021. Estimativa da População, Estimativas de população enviadas ao TCU, atualizado em $31 / 03 / 2021$. https://www.ibge.gov.br/estatisticas/sociais/populacao/9103-estimativas-de-populacao.html?=\&t=resultados.

Junior, B. S. G., Magalhães, I. A. L., Freitas, C. A. A. De \& Cecílio, R. A. (2012). Análise de técnicas de interpolação para espacialização da precipitação pluvial na bacia do rio Itapemirim (ES). Ambiência. Guarapuava (PR) 8(1), 61 - 71

Mazzini, P. \& Schettini, C. (2009). Avaliação de metodologias de interpolação espacial aplicadas a dados hidrográficos costeiros quase-sinóticos. Brazilian Journal of Aquatic Science and Technology. 13. 10.14210/bjast.v13n1.p53-64.

Medeiros, R. M., Holanda, R. M.; Saboya, L. M. F.; Rolim Neto, F. C., Araujo, W. R., \& França, M. V.. Espacialização pelo método da Krigagem nas variabilidades pluvial, evapotranspiração e evaporação no Estado do Pernambuco - Brasil. Research, Society and Development, 10(2), e51010212758, 2021. DOI: $10.33448 /$ rsd-v10i2.12758.

Mello, Y. R. \& De Oliveira, T. M. N. (2016). Análise estatística e geoestatística da precipitação média para o município de Joinville (SC). Revista Brasileira de Meteorologia. DOI: https://doi.org/10.1590/0102-778631220150040.

QGIS 2.18. QGIS Geographic Information System. QGIS Association. http://www.qgis.org.

Pires, C. A. da F., Reis, J. T., Dullius, A. I. dos S., Priensnitz, M. C.\& Pereira, M. J. (2016). Krigagem ordinária aplicada à precipitação pluviométrica nos estados do rio grande do sul e santa catarina. Ciência e Natura, Universidade Federal de Santa Maria, 38(3), 1303-1311.

Samperi, R. H., Collado, C. F. \& Lucio, M. del P. B, (2013). Metodologia Científica. (5a ed.), Penso. 624 p

Santos, W.O., Silva, K.B., Coelho, D. C. L., Silva, K. M. P., Sobrinho, J. E., Silva, P.C.M. \& Batista, R. O. (2014). Variabilidade espacial e temporal das precipitações para a Microrregião de Pau dos Ferros - RN. Revista Brasileira de Geografia Fisica, 7(3), 434-441. https://doi.org/ 10.26848/rbgf.v7.3.p434441.

Shepard, D. (1968) A two-dimensional interpolation function for irregularly-spaced data. Proceedings of the 1968 ACM National Conference, 27-29 August 1968, 517-524.http://dx.doi.org/10.1145/800186.810616.

Silva, R. O. B., Montenegro, S. M.G. L. \& Souza, W.M. (2017). Trends of climate changes in the rainfall in river basins of the state of Pernambuco. Engenharia Sanitaria e Ambiental. 22. 579-589. 10.1590/s1413-41522017142481.

Soares, F. S., Francisco, C. N. \& Senna, M. C.A. (2014). Distribuição espaço-temporal da precipitação na Região Hidrográfica da Baía da Ilha Grande-RJ. Revista Brasileira de Meteorologia. 29. 125-138. 10.1590/S0102-77862014000100012.

World Meteorological Organization. http://worldweather.wmo.int/pt/home.html.

Yamamoto, J. K., \& Landim, P. M. B. (2013). Geoestatística: conceitos e aplicações. Oficina de Textos. 